\title{
Phytogenic additive Noni (Morinda citrifolia) in feed of confined lambs
}

\section{Aditivo fitogênico Noni (Morinda citrifolia) em rações de cordeiros confinados}

\author{
Luiz Juliano Valerio Geron ${ }^{1 *}$; Luiz Eduardo Cantão Veloso ${ }^{2}$; Eduardo Henrique \\ Bevitori Kling de Moraes ${ }^{3}$; Kamila Adreatta Kling de Moraes ${ }^{3}$; Helen Fernanda \\ Barros Gomes ${ }^{3}$; Suellem Fernanda Perosa Zanin ${ }^{4}$; Geovany Macêdo Carvalho5; \\ Thaís Ribeiro Brito ${ }^{5}$; Priscila dos Santos Silva; ${ }^{5}$ Thaís Andrade Almeida ${ }^{5}$
}

\begin{abstract}
The objective of this study was to evaluate the inclusion of different levels of $0.0 \% ; 0.7 \% ; 1.4 \%$ and $2.1 \%$ of Noni (Morinda citrifolia) in the feeding of lambs regarding ingestive behavior and physiological variables. The experiment was carried out in a double Latin $(4 \times 4)$ experimental design with eight animals, consisting of four periods and four experimental rations. Eight lambs with no defined racial pattern were used, with mean initial body weight (BW) of $23.74 \pm 1.00 \mathrm{~kg}$. The ingestive behavior was performed during 24 hours, always on the last day of each experimental period. The physiological variables and the environmental variables were measured during three days of each period. Data were submitted for analysis of variance and, when significant, regression equation was applied at $5 \%$ of probability. Statistical analysis was performed considering the subdivision of the plot, which consisted of the diurnal and nocturnal evaluation times for the ingestive behavior and the morning and afternoon periods for the physiological variables. The inclusion of Noni in fed lambs did not change $(p>0.05)$ the time spent with ingestive behaviors for dry matter intake (DMI), rumination (RUM), idleness (IDL), water intake (WIN) and other activity (OAC). However, the daytime During the period there was gr eater $(p<0.05)$ time use for DMI, WIN and OAC. Inclusion of Noni to diets provided higher $(p>0.05)$ time use during the night time for RUM and IDL. The physiological variables were not influenced ( $p>$ $0.05)$ by the inclusion of Noni in the diets of lambs. However, higher mean $(p<0.05)$ body temperature of the front and rear, rectal temperature and respiratory rate of the lambs were observed during the afternoon. The inclusion of up to $2.1 \%$ of Noni in lamb feed does not alter ingestive behavior and physiological variables. However, the consumption of dry matter and water is higher during the diurnal period, while rumination and idleness are more active during the night period.
\end{abstract}

Key words: Body temperature. Idleness. Respiratory rate. Rumination.

1 Prof., Universidade do Estado de Mato Grosso, UNEMAT, Pontes e Lacerda, MT, Brasil. E-mail: ljgeron@unemat.br

2 Discente de Mestrado, Programa de Pós-Graduação em Zootecnia, Universidade Federal de Mato Grosso, UFMT, Sinop, MT, Brasil. E-mail: duducantao@hotmail.com

3 Profs., UFMT, Sinop, MT, Brasil. E-mail: edukling@ufmt.br; kamila@ufmt.br; gomesh@ufmt.br

4 Discente de Doutorado, Programa de Pós-Graduação em Ciência Animal, UFMT, Cuiabá, MT, Brasil. E-mail: suellemfpzanin@ gmail.com

5 Discentes do Curso de Bacharelado em Zootecnia, UNEMAT, Pontes e Lacerda, MT, Brasil. E-mail: geovany.zootecnia.go@ hotmail.com; zootec.thaisribeiro@hotmail.com; pri.santos92@hotmail.com; thais.a.a@hotmail.com

* Author for correspondence 


\section{Resumo}

Objetivou-se avaliar a inclusão de diferentes teores $0,0 \% ; 0,7 \% ; 1,4 \%$ e 2,1\% de Noni (Morinda citrifolia) na alimentação de cordeiros quanto ao comportamento ingestivo e às variáveis fisiológicas. Adotou-se o delineamento experimental em quadrado latino duplo $(4 \times 4)$ com oito animais, consistindo de quatro períodos e quatro rações experimentais. Foram utilizados 8 cordeiros sem padrão racial definido, com peso corporal (PC) inicial médio de $23,74 \pm 1,00 \mathrm{~kg}$. O comportamento ingestivo foi realizado durante 24 horas, sempre no último dia de cada período experimental. As variáveis fisiológicas e as variáveis ambientais foram mensurados durante três dias de cada período. Os dados foram submetidos à análise de variância e, quando significativos, aplicou-se equação de regressão a 5\% de probabilidade. A análise estatística foi procedida considerando a subdivisão da parcela, as quais consistiram dos tempos de avaliação diurno e noturno para o comportamento ingestivo e períodos manhã e tarde para as variáveis fisiológicas. A inclusão de Noni na alimentação de cordeiros não alterou $(\mathrm{p}>0,05)$ o tempo despendido com as atividades dos comportamentos ingestivo, quanto ao consumo de matéria seca (CMS), ruminação (RUM), ócio (OCI), consumo de água (CAG) e outras atividade (OAT). Porém, durante o período diurno houve maior $(\mathrm{p}<0,05)$ utilização do tempo para as atividades de CMS; CAG e OAT. A inclusão do Noni Às dietas proporcionou maior $(\mathrm{p}>0,05)$ utilização do tempo durante o período noturno para RUM e OCI. As variáveis fisiológicas não foram influenciadas $(\mathrm{p}>0,05)$ pela inclusão do Noni às dietas dos cordeiros. Contudo foram observadas maiores médias $(\mathrm{p}<0,05)$ de temperatura corporal do dianteiro e traseiro, temperatura retal e frequência respiratória dos cordeiros durante o período da tarde. A inclusão de até $2,1 \%$ de Noni na alimentação de cordeiros não altera o comportamento ingestivo e as variáveis fisiológicas. Porém, o consumo de matéria seca e de água é maior durante o período diurno, enquanto a ruminação e o ócio se apresentar mais ativos durante o período noturno.

Palavras-chave: Comportamento ingestivo. Frequência respiratória. Temperatura corporal.

\section{Introduction}

The search $\mathrm{s}$ with natural products phytogenic animals are poorly explored the (CATALAN et al., 2013), therefore, studies that prove their effectiveness are scarce, but the sector is growing and jobs are the most varied (WANG et al., 2002; GERON et al., 2019) mainly in increasing the resistance of the animal organism against diseases, intoxications or environmental problems, mode of action that these natural foods act on the consumption and digestion, avoiding immunosuppression, stress and, consequently, reduced animal performance.

According to Bontempo (2007), functional foods are part of an elite group of nutrients. Besides having nutrients, functional foods also have components of protective, medicinal, therapeutic and special curative action, all these characteristics make functional foods beneficial to human and animal health.
In recent years research on medicinal plants has increased considerably (RODRIGUEZ-PRADO et al., 2011; PINTO et al., 2013). Some traditional species have been the starting point for the manufacture of important medicines Tagliati et al. (2008).

The Noni (Morinda citrifolia) has a low protein content and lipids, consisting pre dominantly of carbohydrates, sugars and fibers (CUNHA et al., 2012). In addition, Noni contains large amounts of vitamin $\mathrm{C}$, and substantial amounts of niacin (vitamin B3), potassium and iron. Noni fruit usually has a concentration of $216.67 \mathrm{mg}$ Golic acid equivalent - EAG of total phenolics $100^{-1} \mathrm{~g}$, which is a natural antioxidant (CORREIA et al., 2011). Phenolic compounds act as antioxidants not only for their ability to donate hydrogen or metal chelating electrons, but also because of their stable intermediate radicals, which prevent the oxidation of various food constituents, particularly fatty acids and oils (SOARES et al., 2008). 
Phenolic compounds have been widely studied for their influence on food quality and their constitution that has antioxidant properties (SOARES, 2002). In addition, some gallic acid derivatives, the gallates, have been shown to inhibit the respiratory chain of the Trypanossoma cruzi parasite (LETELIER et al., 1990), antimicrobial activity against Escherichia coli (BOYD; BEVERIDGE, 1981) and rat hepatocyte toxicity. contributing to mitochondrial dysfunction (NAGAKAWA; TAYAMA, 1995). Thus, there is a possibility that the use of functional foods with phytogenic origin may alter the rumen fermentative activity and consequently the ingestive behavior of ruminants.

The result of Noni is presented as phytogenic potential additive in animal feed, since this is expanded in Brazil, and has the ability to adapt to any soil, besides presenting a considered quantity of gallic acid (CORREIA et al., 2011). In general, antioxidants are substances capable of inhibiting or retarding the oxidation of sensitive structures when present in minute concentrations (ANGELLA, 2014). In organism lives, the existence of an imbalance in favor excessive generation of radicals, or instead of removal rate of this species reactive known as oxidative stress in the long term, this stress in the cellular environment, can cause severe problems metabolic and be Wrapped into degenerative diseases (SHAMI; MOREIRA, 2004).

Evaluation of pulp extract, noni seed and bark as an additive natural was conducted by Costa et al. (2013) indicated that acetonic pulp extract, quantified $109.81 \mathrm{mg} / 100 \mathrm{~g}$ of total phenolics, followed by acetone extracts of the shell (76.01 $\mathrm{mg} / 100 \mathrm{~g})$ of seeds $(28.75 \mathrm{mg} / 100 \mathrm{~g})$. Thus, the authors concluded that all the $\mathrm{s}$ fractions of Noni fruit have antioxidant activity in vitro, due to the presence of phenolic compounds and gallic acid.

Review performed by Wang et al. (2002), to verify the antimicrobial action of Noni extract indicated that this activity is mainly related to the presence of anthraquinones and phenolic compounds present in their chemical composition of the fruit. These compounds are responsible for preventing the attack of infectious bacterial strains.

Search with different levels of Noni $(0,8,16$ and 24\%) as an alternative food source of protein to ruminants were subjected to fermentation in vitro by Geron et al. (2019). The authors observed a range of variation of $6 \%$ between $0 \%$ Noni and $24 \%$ Noni diets. They suggested that new study s should be carried out are, to verify that the use of Noni can act phytogenic additive for ruminants.

The feeding behavior of animal knowledge provides for better air feeding management and, consequently, the change so positive results production (BREMM et al., 2008). The feedlot sheep exhibit ingestive behavior as a function of roughage nutritive value, acceptability, particle size and physical form. The first factor that affects this activity is neutral detergent fiber (NDF), since they intervene directly in the ruminal kinetics (YANG et al., 2001).

The animal may alter its ingestive behavior when there is a change in food or the addition of food additives (GONÇALVES et al., 2000). Also, in situations where the animal is outside its comfort zone, it suffers from what we call stress. This way, if the animal is under stress, it can pass by situations that depend on several factors (leakage, curious, alert, fear, etc.), which can be evidenced by evaluation of animal ethology and dietary behavior (DADO; ALLEN, 1994).

The objective of this study was to evaluate the inclusion of Noni (Morinda citrifolia) in lambs feeding, ingestive behavior and physiological variables.

\section{Material and Methods}

The experiment was conducted in Setor de Metabolismo Animal (SeMA) of the Universidade do Estado de Mato Grosso (UNEMAT) and the chemical analysis of ingredients and feed were 
carried out in Laboratório de Análise de Alimentos e Nutrição Animal (LAANA).

The experimental design was double Latin square (4X4) with eight animals (lambs), consisting of four periods and four experimental rations with $0.0 \% ; 0.7 \% ; 1.4 \%$ and $2.1 \%$ of Noni to lamb's feedlot. Eight crossbred lambs with average initial body weight (BW) of $23.74 \pm 1 \mathrm{~kg}$ were used in the test of total nutrient digestibility and ingestive behavior. The lambs were housed in individual pens (metabolism cages), each cage contained a feeder and an individual polyethylene drinker.

For evaluates ingestive behavior and the physiological variables were considered are two periods as subplots, and day (7:00 a.m. to 18h59) and evening (19:00 pm to 6h59) for ingestive behavior variables (GERON et al., 2018) and the time the morning (7:00 a.m to $11 \mathrm{~h} 00)$ and late (13:00 a.m. to 17h00) for physiological variables lambs (GERON et al., 2018).

The fruit of the Noni was harvested on plantations not trade in the southwest of the State of Mato Grosso, in the municipality of Pontes e Lacerda, during the months from May to June 2015. The fruits of Noni in natura were processed in crusher with sieve the screens $10 \mathrm{~mm}$ and, in sequence, was dried in the sun for approximately $96 \mathrm{H00}$ layered approximately $5 \mathrm{~cm}$ above a plastic sheet.

The diets with inclusion of Noni were balanced second requirements NRC (2007) for lambs, aiming average daily gain of $150 \mathrm{~g} \mathrm{pet}^{-1}$, to be isonitrogenous and isoenergetic using the ingredients concentrated corn ground grain, soybean and Noni dried and the roughage was corn silage (Tables 1 and 2), in the ratio 35:65, respectively. The water and the salt mineral were available in individual troughs at ease. The rations were provided twice a day (at 8:00 am and 4:00 pm), so that there were approximately $10 \%$ of leftovers daily.

The experiment lasted 84 days, divided into four experimental periods of 21 days each, 14 days for adaptation of animals and 7 days of data collection (behavioral and physiological), food samples and leftovers. During the experimental period, management was performed as described by Geron et al. (2018).

Table 1. Chemical composition of the experimental feed ingredients.

\begin{tabular}{lcccc}
\hline \multirow{2}{*}{\multicolumn{1}{c}{ Variables }} & \multicolumn{4}{c}{ Experimental foods $\left(\mathrm{g} \mathrm{kg}^{-1}\right)$} \\
\cline { 2 - 5 } & $\mathrm{CS}^{1}$ & $\mathrm{CG}^{2}$ & $\mathrm{SM}^{3}$ & Noni $^{4}$ \\
\hline Dry matter (DM) & 346.60 & 910.00 & 926.80 & 900.90 \\
Organic matter (OM) & 932.00 & 983.60 & 933.70 & 905.00 \\
Crude protein (CP) & 72.50 & 89.80 & 491.60 & 57.20 \\
Ethereal Extract (EE) & 30.90 & 38.50 & 17.30 & 13.30 \\
Neutral detergent fiber (NDF) & 552.20 & 142.70 & 153.50 & 7.30 \\
Acid Detergent Fiber (FDA) & 311.30 & 42.30 & 96.30 & 194.70 \\
Crude Fiber (CF) & 249.00 & 33.80 & 77.00 & 155.80 \\
Non Nitrogen Extractive (NNE) & 597.30 & 821.40 & 350.20 & 688.20 \\
Total Carbohydrates (TC) & 829.60 & 855.30 & 424.70 & 834.80 \\
Non-fibrous Carbohydrate (NFC) & 276.90 & 713.10 & 271.20 & 827.50 \\
Mineral Matter (MM) & 50.30 & 16.40 & 63.80 & 85.60 \\
Total Digestible Nutrients (TDN) & 631.20 & 860.30 & 807.20 & 750.00 \\
Equivalent gallic acid mg $100^{-1} \mathrm{~g}^{*}$ & - & - & - & 216.67 \\
\hline
\end{tabular}

${ }^{1}$ corn silage, ${ }^{2}$ ground corn grain, ${ }^{3}$ soybean meal, ${ }^{4}$ dehydrated noni, ${ }^{*}$ values obtained by Correia et al. (2011). 
The samples are of food and remains were dried at $55{ }^{\circ} \mathrm{C}$ for $72 \mathrm{~h} 00$, and processed in a mill type Willey, using sieve 1 sieves, $0 \mathrm{~mm}$, then mixed in equal amounts, separately, based on dry weight, to form samples composed of animal food and leftovers experimental period ${ }^{-1}$ ration $^{-1}$.

The nitrogen content, with consequent estimate of crude protein $(\mathrm{CP})$ and determining the mineral matter (MM) and ether extract (EE) of the food and the remains as well as the estimate of organic matter (OM) were obtained are second methodologies described by Silva and Queiroz (2002). The estimate of the content of neutral detergent fiber (NDF) and acid detergent fiber (ADF) of the food remnants and faeces were performed according to Van Soest et al. (1991).

Table 2. Percentage and chemical composition of Noni- containing experimental diets fed to lambs.

\begin{tabular}{lcccc}
\hline \multirow{2}{*}{\multicolumn{1}{c}{ Foods }} & \multicolumn{4}{c}{ Noni inclusion levels in experimental diets } \\
\cline { 2 - 5 } & 0,0 & 0,7 & 1,4 & 2,1 \\
\hline Corn Silage (CS) & 65.00 & 65.00 & 65.00 & 65.00 \\
Corn grain (CG) & 21.00 & 21.00 & 20.30 & 19.90 \\
Soybean meal (SM) & 14.00 & 13.30 & 13.30 & 13.00 \\
Noni & 0.00 & 0.70 & 1.40 & 2.10 \\
Total & 100.00 & 100.00 & 100.00 & 100.00 \\
\hline Bromatological composition & & & $\mathrm{g} \mathrm{kg}^{-1}$ & \\
Dry Matter (DM) & 546.10 & 545.90 & 545.90 & 545.80 \\
Organic Matter (OM) & 943.10 & 926.40 & 926.40 & 926.30 \\
Crude Protein (CP) & 134.80 & 131.80 & 131.50 & 130.10 \\
Ethereal Extract (EE) & 30.60 & 30.60 & 20.80 & 20.70 \\
Neutral detergent fiber (NDF) & 410.40 & 409.40 & 408.40 & 407.40 \\
Acid Detergent Fiber (ADF) & 224.70 & 225.40 & 226.50 & 227.40 \\
Total Carbohydrate (TC) & 778.00 & 780.80 & 780.70 & 781.80 \\
Non-fibrous Carbohydrate (NFC) & 367.70 & 371.60 & 372.40 & 374.50 \\
Total Digestible Nutrients (TDN) & 704.00 & 703.60 & 702.80 & 702.20 \\
Equivalent gallic acid mg 100-19 & 0.00 & 1.52 & 3.03 & 4.55 \\
\hline
\end{tabular}

The estimated total carbohydrate (TC) content of food, leftovers and feces was obtained by the equation: $\mathrm{TC}=\mathrm{OM}-[\mathrm{EE}+\mathrm{CP}](\mathrm{SNIFFEN}$ et al., 1992). The non-fibrous carbohydrate (NFC) content of food, leftovers and feces was estimated by the equation: $\mathrm{NFC}=100-(\mathrm{CP}+\mathrm{NDF}+\mathrm{EE}+\mathrm{MM})$ according to Sniffen et al. (1992).

The ingestive behavior of the animals was performed on the first day of each collection period. Throughout the experimental period, artificial lighting was maintained at night so that animals could adapt to the environment to collect ingestive behavior data (GERON et al., 2018).

The sheep were subjected to visual observation to evaluate the ingestive behavior variables, and were observed every five minutes for $24 \mathrm{~h} 00$ to determine the time spent for dry matter intake (DMI), rumination (RUM), idleness (IDL), water consumption (WC) and other activities (OAT), the latter is related to activities that do not fit in with any other described above (eg playing, scratching, mineral salt consumption, etc.). which were measured for four non-consecutive days (JOHNSON; COMBS, 1991). 
The total time of each activity observed in the different periods (day and night) was obtained by summing the total number of times each sheep was in a given state following the recommendations of Souza (2007).

As for the physiological parameters, evaluate $u$ is the respiratory frequency (RF), rectal temperature (RTH), the front body temperature (FBT), the rear body temperature (RBT) measured over three days in each period experimental at the times of 7:00 a.m. and 11h00 (morning) and 13h00 and 17h00 (afternoon), as described by (SILVA et al., 2015).

The RTH was measured with a clinical thermometer introduced into the animal's rectum for two minutes, and the RF by visual observation for 15 seconds, of how many times the animal's flank inspires and expires, and the result multiplied by four, thus obtaining the frequency $\min ^{-1}$. The FBT and RBT obtained using a digital infrared thermometer, obtaining the FBT in the palette region of the animal's thigh.

The environmental variables recorded were the ambient temperature (AmT) by means of a taco thermometer; the dry bulb (DBT) and wet bulb (WBT) temperature by the analog dry bulb and wet bulb thermometer, respectively; and maximum and minimum temperature, the temperature thermometer analog maximum and minimum, respectively (VERÍSSIMO et al., 2009).

The physiological data were collected during three days of each experimental period, from the second to the fourth day of each collection period. The relative humidity (\%) was obtained by using the SD (saturation deficit) $=\mathrm{Th}-\mathrm{Tu}$, where Ts is the dry bulb temperature unless the temperature of the bulb wet (BSCS, 1970). The wet bulb temperature and saturation deficit $(\Delta \mathrm{T})$ data were interpolated in the saturated vapor pressure table as a function of the temperature to obtain the relative humidity $(\mathrm{RH})$ of the air (\%).

Lambs fed diets containing $0.0 \%$ inclusion; $0.7 \%$; Noni $1.4 \%$ and $2.1 \%$ were housed in metabolism cages located in an area covered by fiber cement, which presented a range of variation for air temperature (AT); dry bulb (DB) and wet bulb (WB) and relative humidity $(\mathrm{RH})$ as described in Table 3. The ambient temperature values were higher in the afternoon than in the morning. Relative humidity values ranged from $43 \%$ to $56 \%$, and a lower $\mathrm{RH}$ was observed for the afternoon (Table 3).

Table 3. Medium variable climate in the region Southwest d the state of Mato Grosso.

\begin{tabular}{ccc}
\hline Climate Variables & Morning & Evening \\
\hline AmT $\left({ }^{\circ} \mathrm{C}\right)$ & 26.9 & 32.3 \\
$\mathrm{DBT}\left({ }^{\circ} \mathrm{C}\right)$ & 28.1 & 33.1 \\
$\mathrm{WBT}\left({ }^{\circ} \mathrm{C}\right)$ & 21.3 & 24.1 \\
$\mathrm{RH}(\%)$ & 53.0 & 46.0 \\
\hline
\end{tabular}

Ambient Temperature (AmT), Dry Bulb (DBT), Wet Bulb (WBT) and Relative Humidity (RH).

Data were analyzed by analysis of variance using the System of Statistical and Genetic Analysis - SAEG (UFV, 2007). For feeding behavior data and physiological variables statistical analysis was preceded considering the subdivision of the plot, considering the periods of day and night rating for feeding behavior and the times of the morning and the afternoon to the physiological variables. When significant, the mean subplots were compared by the test of Tukey and for Noni inclusion levels, applied equations regression, considering $5 \%$ probability. 


\section{Results and Discussion}

The addition of Noni in dieting $\mathrm{d}$ the lambs not changed $(\mathrm{P}>0.05)$ the parameters of the behavior intake, as the time taken for dry matter intake (DMI), rumination (RUM), idleness (IDL), water consumption (WC) and other activity (OAT) for the total period of $24 \mathrm{~h} 00$, with average values of 252; 484; 550; 13 and 141 min day $^{-1}$, respectively (Table 4). This small variation in the NDF and NFC levels of the experimental diets, with average values of $40.89 \%$ and $37.16 \%$, respectively, may have corroborated the data on the ingestive behavior of sheep fed with different Noni levels. Since the inclusion of Noni sought nutritional levels in the diet. Furthermore, the different levels Noni provided a gallic acid equivalent concentration ranging from 0 to $4.55100 \mathrm{mg}^{-1} \mathrm{~g}$, this fact indicated that the levels used Noni did not promote changes in the rumen environment, which could have changed the rate of passage and time of retention ration and therefore have changed the feeding behavior of sheep.

Table 4. Ingestive behavior (expressed in minutes) of lambs fed diets containing the inclusion of different Noni levels for the $24 \mathrm{~h} 00$ period and coefficient of variation.

\begin{tabular}{|c|c|c|c|c|c|c|}
\hline \multirow{2}{*}{ Activity } & \multicolumn{4}{|c|}{ Levels of inclusion of Noni in experimental rations } & \multirow{2}{*}{ Regression } & \multirow{2}{*}{$\% \mathrm{CV}$} \\
\hline & 0,0 & 0,7 & 1,4 & 2,1 & & \\
\hline DMI min. dia ${ }^{-1}$ & 246 & 256 & 252 & 253 & $\hat{\mathrm{Y}}=252$ & 21.65 \\
\hline RUM min. dia ${ }^{-1}$ & 493 & 466 & 489 & 488 & $\hat{Y}=484$ & 13.21 \\
\hline IDL min. dia $^{-1}$ & 560 & 562 & 556 & 524 & $\hat{\mathrm{Y}}=550$ & 15.58 \\
\hline WC min. dia $^{-1}$ & 14 & 12 & 12 & 14 & $\hat{\mathrm{Y}}=13$ & 83.83 \\
\hline OAT min. dia ${ }^{-1}$ & 127 & 144 & 131 & 161 & $\hat{\mathrm{Y}}=141$ & 29.34 \\
\hline Total min. dia ${ }^{-1}$ & 1.440 & 1.440 & 1.440 & 1.440 & - & - \\
\hline
\end{tabular}

$\mathrm{DMI}=$ Feed intake, RUM = Rumina tion, $\mathrm{WC}$ : water consumption, IDL = Other Activities. Regression value equal to mean for values with $\mathrm{p}>0.05$.

Study by Macedo et al. (2007), to evaluate the ingestive behavior of sheep receiving diets with different levels of orange pomace $(0 ; 25 ; 50$ and $75 \%$ ) observed that the DMI presented an average undressing time of $405 \mathrm{~min}$ day ${ }^{-1}$. However, the authors used diets with average levels of $8 \% \mathrm{CP}$ and $68 \%$ TDN, which provided a longer time spent for feed intake.

A study to evaluate the inclusion of Noni in balanced diets for sheep submitted to in vitro fermentation was conducted by Geron et al. (2018). The authors indicated the $\mathrm{pH}$ content fermented after incubation for 24 hours showed a maximum point, and suggested that Noni could alter the environment brew will and consequently the production and feeding behavior. However, the inclusion of up to $2.1 \%$ Noni as phytogenic additive feed for lambs provided a level of $4.55 \mathrm{mg}$ equivalent gallic acid $100^{-1} \mathrm{~g}$, and this not been satisfactory and / or facilitated changes in behavior ingestive.

Time spent on DMI, RUM, IDL, WC and OAT was influenced $(\mathrm{P}<0.05)$ by day and night periods (Table 5). The effect of these activities observed over periods of ingestive behavior is correlated with the environmental variables, which corroborated the data obtained, since temperature milder next track thermal comfort were obtained at the beginning of the period morning (26.9 the $\mathrm{C}$ ), however the end the afternoon and early evening at room temperature was 32.3 the $\mathrm{C}$ (Table 3 ). 
Table 5. Ingestive behavior (expressed in minutes) of lambs fed different levels of Noni for the day and night periods.

\begin{tabular}{|c|c|c|c|c|c|c|c|}
\hline \multirow{2}{*}{ Activity } & \multirow{2}{*}{ Period } & \multicolumn{4}{|c|}{ Noni inclusion levels in experimental diets } & \multirow{2}{*}{ Regression } & \multirow{2}{*}{$\% \mathrm{CV}$} \\
\hline & & 0,0 & 0,7 & 1,4 & 2,1 & & \\
\hline \multirow[t]{2}{*}{ DMI min. } & Daytime & 166 & 180 & 169 & 178 & $\hat{\mathrm{Y}}=173 \mathrm{a}$ & 32.70 \\
\hline & Night & 66 & 66 & 77 & 70 & $\hat{\mathrm{Y}}=71 \mathrm{~b}$ & \\
\hline \multirow[t]{2}{*}{ RUM min. } & Daytime & 189 & 179 & 189 & 192 & $\hat{\mathrm{Y}}=187 \mathrm{~b}$ & 23.51 \\
\hline & Night & 304 & 287 & 301 & 296 & $\hat{\mathrm{Y}}=297 \mathrm{a}$ & \\
\hline \multirow[t]{2}{*}{ IDL min. } & Daytime & 256 & 234 & 243 & 249 & $\hat{\mathrm{Y}}=246 \mathrm{~b}$ & 51.71 \\
\hline & Night & 304 & 328 & 313 & 276 & $\hat{\mathrm{Y}}=305 \mathrm{a}$ & \\
\hline \multirow[t]{2}{*}{ WC min. } & Daytime & 13 & 11 & 12 & 12 & $\hat{\mathrm{Y}}=12 \mathrm{a}$ & 49.23 \\
\hline & Night & 1 & 1 & 1 & 1 & $\hat{Y}=1 b$ & \\
\hline \multirow[t]{2}{*}{ OAT min. } & Daytime & 84 & 89 & 73 & 96 & $\hat{\mathrm{Y}}=86 \mathrm{a}$ & 21.71 \\
\hline & Night & 43 & 55 & 58 & 64 & $\hat{\mathrm{Y}}=55 \mathrm{~b}$ & \\
\hline
\end{tabular}

Period (day and night) within ration; DMI = Feed Consumption, RUM = Ruminando, IDL: idleness; WC: water consumption, OAT $=$ Other activities. Min.: minutes. Regression value equal to mean for values with $p>0.05$. Different lowercase letters in the column differ from each other $(\mathrm{p}<0.05)$.

The more time spent $(\mathrm{P}<0.05)$ for the activities of DMI, WA and OAT in daytime with mean values of $173 ; 12$ and 86 min day $^{-1}$, respectively in relation to the night period with $71 ; 1$ and 55 min day $^{-1}$, respectively, are related to the sheep ethology itself, which present larger activities in general for the daytime and, consequently, longer time used for feed and water consumption. Another factor, which may help to understand these values, is correlated with the roaring, which occurred at $8 \mathrm{~h} 00$ and $16 \mathrm{~h} 00$, during the daytime, which stimulates feed intake. The higher feed intake during day time and high ambient temperature of 32.3 The $\mathrm{C}$ during the afternoon, were factors which contributed to the greatest WA during this period, in relation to night.

The activity DMI has May relevance during the daytime, in ovine and, consequently, the higher dry matter intake provides a greater stimulus to WC, which facilitates the swallowing of food and processes digestive and metabolic the food and nutrients (ARAÚJO et al., 2011).

Observed is the sheep fed diets containing Noni presented May time $(\mathrm{P}<0.05)$ spent on the activity of RUM and IDL during the night period (Table 5).
These results are correlated with the gregarious habit and protection of sheep against predators, the which might $\mathrm{m}$ reduces the activity are physically s during the night (BERCHIELLI et al., 2006). In addition, the daytime feeding hours favored the longer time spent for RUM and IDL during the night time.

A study by Michailoff et al. (2015), to evaluate the ingestive behavior of sheep confined those in the northeastern semiarid, obtained average 300 minutes to the time taken for the IDL activity during the period day, value above that found in 246 minutes this study.

The inclusion of Noni in the sheep diet did not change $(\mathrm{P}>0.05)$ the front body temperature (FBT), the rear body temperature (RBT), rectal temperature (RT) and respiratory frequency (RF) regardless of the time evaluated morning or afternoon (Table 6). However, it was observed that the different times evaluated morning and afternoon influenced $(\mathrm{P}<0.05)$ these variables. Highers $(\mathrm{P}<0.05)$ FBT and RBT were observed during the afternoon, with a mean of 35.94 and $35.87^{\circ} \mathrm{C}$, respectively, in relation to the morning time, with mean values of 32.16 and $32.48^{\circ} \mathrm{C}$ respectively (Table 6 ). 
Table 6. Physiological variables of lambs fed different levels of Noni for the morning and afternoon hours.

\begin{tabular}{cccccccc}
\hline \multirow{2}{*}{ Variables } & \multirow{2}{*}{ Schedule } & \multicolumn{9}{c}{ Levels of inclusion of Noni in experimental rations } & \multirow{2}{*}{ Regression } & \multirow{2}{*}{$\% \mathrm{CV}$} \\
\cline { 2 - 5 } & & 0,0 & 0,7 & 1,4 & 2,1 & & \\
\hline FBT $\left({ }^{\circ} \mathrm{C}\right)$ & Manhã & 32.07 & 32.23 & 32.09 & 32.25 & $\hat{\mathrm{Y}}=32.16 \mathrm{~b}$ & 8.50 \\
& Tarde & 36.03 & 36.14 & 35.82 & 35.76 & $\hat{\mathrm{Y}}=35.94 \mathrm{a}$ & \\
\hline RBT $\left({ }^{\circ} \mathrm{C}\right)$ & Manhã & 32.66 & 32.72 & 32.49 & 32.03 & $\hat{\mathrm{Y}}=32.48 \mathrm{~b}$ & 7.69 \\
& Tarde & 35.99 & 35.91 & 36.05 & 35.51 & $\hat{\mathrm{Y}}=35.87 \mathrm{a}$ & \\
\hline RT $\left({ }^{\circ} \mathrm{C}\right)$ & Manhã & 37.86 & 38.94 & 38.97 & 38.40 & $\hat{\mathrm{Y}}=38.54 \mathrm{~b}$ & 2.71 \\
& Tarde & 39.27 & 39.31 & 39.27 & 38.77 & $\hat{\mathrm{Y}}=39.16 \mathrm{a}$ & \\
\hline RF & Manhã & 28.00 & 30.00 & 28.00 & 28.00 & $\hat{\mathrm{Y}}=28.50 \mathrm{~b}$ & 29.22 \\
Quant. per min. & Tarde & 36.00 & 40.00 & 38.00 & 40.00 & $\hat{\mathrm{Y}}=38.50 \mathrm{a}$ & \\
\hline
\end{tabular}

FBT $=$ Front body temperature, RBT $=$ Rear body temperature, RT: Retal temperature, RF $=$ Respiratory frequency, Quant. per min. $=$ amount per minute. Regression value equal to mean for values with $p>0.05$. Different lowercase letters in the column differ from each other $(\mathrm{p}<0.05)$.

The addition of Noni in the feeding of sheep did not affect $(\mathrm{P}>0.05) \mathrm{RT}$, however this one was influenced by the morning and afternoon, with greater $(\mathrm{P}<0.05)\left(39.16^{\circ} \mathrm{C}\right)$ for the afternoon to the morning $\left(38.34{ }^{\circ} \mathrm{C}\right)$. Despite the range of variation for RT observed at the evaluated times, these values are close to normal RT and $38.5^{\circ} \mathrm{C}$ to $39.5{ }^{\circ} \mathrm{C}$ for sheep (CUNNINGHAM, 2008).

The RF is higher $(\mathrm{P}<0.05)$ in time afternoon with Medi to the 28.5 and 38.5 movements min $^{-1}$ for morning and afternoon, respectively. This result may have been influenced by the characteristics climate of the region tropical Wonderlands, a since the room temperature showed range of variation $26.9{ }^{\circ} \mathrm{C}$ in the morning to $32,3{ }^{\circ} \mathrm{C}$, in the afternoon , in which they can exert direct influence on the physiological variables of the animals, especially the RF (RASLAN, 2008).

The literature points out that the ambient temperature range, which constitutes the thermal comfort zone for sheep, is from $20{ }^{\circ} \mathrm{C}$ to $27{ }^{\circ} \mathrm{C}$. This way it was observed that at the time morning AmT $26.9{ }^{\circ} \mathrm{C}$ was the recommended. However, during the hours later, RT $32.3^{\circ} \mathrm{C}$ remained above that recommends, second Baêta and Souza (2010). According to Reece (2007), the normal RF for sheep is 16 to $34 \mathrm{~min}^{-1}$ movements. To the extent that the environment shown stressful to the animals, the physiologic system triggers $m$ heat dissipation mechanisms.

The inclusion of Noni as a phytogenic additive in sheep diets does not influence the ingestive behavior and does not change the physiological parameters of finishing sheep. Up to $2.1 \%$ of Noni is recommended in the diet.

\section{References}

ANGELLA, F. C. O. Avaliação da atividade antioxidante em extratos de frutas típicas do cerrado brasileiro. 2014. Dissertação (Mestrado em Ciências) - Instituto de Química de São Carlos, Universidade de São Paulo, São Carlos.

ARAÚJO, G. G. L.; VOLTOLINI, T. V.; TURCO, S. H. N.; PEREIRA, L. G. R. A água nos sistemas de produção de caprinos e ovinos. In: VOLTONINI, T. V. (Ed.). Produção de caprinos e ovinos do semiárido, 2011. Petrolina: Embrapa Semiárido, 2011. p. 123-150. Disponível em: https://www.alice. cnptia.embrapa .br/ alice/simple-search?query $=$ Produ $\% \mathrm{C} 3 \% \mathrm{~A} 7 \% \mathrm{C} 3 \% \mathrm{~A} 3 \mathrm{o}+$ de+caprinos+e+ovinos + no + semi $\%$ C3\%A1rido \&sort $\mathrm{by}=\mathrm{score} \&$ order $=\operatorname{desc} \& \mathrm{rpp}=10 \& \mathrm{etal}=0 \& \mathrm{start}=10^{-}$. Acesso em: 05 set. 2019.

BAÊTA, F. C.; SOUZA, C. F. Ambiência em edificações rurais: conforto animal. 2. ed. Viçosa, MG: UFV, 2010. 
$246 \mathrm{p}$.

BERCHIELLI, T. T.; PIRES, A. V.; OLIVEIRA, S. G. Nutrição de ruminantes. Jaboticabal: Funep, 2006. 583 p.

BONTEMPO, M. Pimenta e seus beneficios a saúde. São Paulo: Alaúde, 2007. 100 p.

BOYD, L.; BEVERIDGE, E. G. Antimicrobial activity of some alkyl esters of gallic acid (3,4,5 trihidroxybenzoic acid) against esterichia cold NCTC 5933 with particular reference to n-propyl gallate, Microbios, Bethesda, v. 120, n. 30, p. 73-85, 1981. DOI: PMID: 6272069

BREMM, C.; SILVA, J. H. S.; ROCHA, M. G.; ELEJALDE, D. A. G.; OLIVEIRA NETO, R. A.; CONFORTIN, A. C. Comportamento ingestivo de ovelhas e cordeiras em pastagem de azevém anual sob níveis crescentes de suplementação. Revista Brasileira de Zootecnia, Viçosa, MG, v. 37, n. 12, p. 2097-2106, 2008. DOI: $10.1590 / \mathrm{S} 1516-35982008001200004$

BIOLOGICAL SCIENCE CURRICULUM STUDY BSCS. Biología. Su enseñanza moderna. Buenos Aires: Editorial Estrada, 1970.

CATAlan, A. A. S.; ÁVILA, F. V.; AVILA, V. S. (2013). Perspectivas de utilização de aditivos fitogênicos na produção animal. Infoteca: Embrapa, Pelotas, v. 23, n. 1, 2013. Disponível em: https://www.infoteca.cnptia. embrapa.br/bitstream/doc/979424/1/final7358.pdf. Acesso em: 05 set. 2019.

CORREIA, A. A. S.; GONZAGA, M. L. C.; AQUINO, A. C.; SOUZA, P. H. M.; FIGUEIREDO, R. W.; MAIA, G. A. Caracterização química e fisioquímica da polpa do noni (Morinda citrifolia) cultivado no estado do Ceará. Alimentos e Nutrição, Araraquara, v. 22, n. 4, p. 609-615, 2011.

COSTA, A. B.; OLIVEIRA, A. M. C.; SILVA, A. M. O.; MANCINI FILHO, J.; LIMA, A. Atividade antioxidante da polpa, casca e semente do Noni (Morinda citrofolia L). Revista Brasileira de Fruticultura, Jaboticabal, v. 35 , n. 2 , p. $345-354,2013$. DOI: $10.1590 / \mathrm{S} 0100-$ 2945201300020003.

CUNHA, S. X. S.; NASCIMENTO, N. P.; SOUZA, J. P. C.; SOUZA, M. R.; SOUZA, P. A. Caracterização nutricional de frutos de noni (Morindacitrifolia L.) cultivados em Limoeiro do Norte (CE). In: CONNEPI, CONGRESSO NORTE E NORDESTE DE PESQUISA E INOVAÇÃO, 7., 2012, Palmas. Anais... Palmas: Universidade Federal de Tocantins, 2012. CD-ROM. Disponível em: http://propi.ifto.edu.br/ocs/index. php/ connepi/vii/paper/viewFile/3665/3079. Acesso em: 05 set. 2019.

CUNNINGHAM, J. G. Tratado de fisiologia veterinária. 3. ed. Rio de Janeiro: Guanabara Koogan, 2008. 596 p.
DADO, R. G.; ALLEN, M. S. Variation in and relationships among feeding, chewing, and drinking variables for lacting dairy cows. Journal Dairy Science, Champaing, v. 77, n. 1, p. 132-144, 1994. DOI: 10.3168/ jds.S0022-0302(94)76936-8.

GERON, L. J. V.; AGUIAR, S. C.; GARCIA, J.; ZEOULA, L. M.; COELHO, K. S. M.; SANTOS, I. S.; CARVALHO, J. W. P.; SOUZA, A. L.; ZANINE, A. M.; DINIZ, L. C. Distiller's dried grain with solubles (Zea mays $\mathrm{L}$ ) in the diet of sheep reared in the tropical region of Brazil: ingestive behavior and physiological parameters. Semina: Ciências Agrárias, Londrina, v. 39, n. 3, p. $1267-$ 1280, 2018. DOI: 10.5433/1679-0359.2018v39n3p1267

GERON, L. J. V.; VELOSO, L. E. C.; AGUIAR, S. C.; SOUZA, A. L.; SOUZA, I. S.; TRAUTAMN-MACADO, R. J.; ZANINE, A. M.; SILVA, R. F.; FERREIRA, D. J.; ZANIN, S. F. P. In vitro fermentation of the rations containing Morinda citrifolia L. (Noni) using two types of inoculum. Semina: Ciências Agrárias, Londrina, v. 40, n. 2, p. 831-842, 2019. DOI: 10.5433/1679-0359

GONÇALVES, A. L.; LANA, R. P.; RODRIGUES, M. T.; VIEIRA, R. A. M.; QUEIROZ, A. C.; HENRIQUE, D. S. Comportamento alimentar de cabras leiteiras submetidas a dietas com diferente relação volumoso:concentrado. In: REUNIÃO ANUAL DA SOCIEDADE BRASILEIRA DE ZOOTECNIA, 37., 2000, Viçosa, MG. Anais... São Paulo: SBZ/Gmosis, 2000. CD-ROM.

JOHNSON, T. R.; COMBS, D. K. Effects of prepartum diet, inert rumen bulk, and dietary polythylene glicol on dry matter intake of lactating dairy cows. Journal of Dairy Science, Champaing, v. 74, n. 3, p. 933-944, 1991. DOI: $10.3168 /$ jds.S0022-0302(91)78243-X

LETELIER, M. E.; RODRIGUEZ, E.; WALACE, A.; LORCA, M.; REPETTO, Y.; MORELlO, A.; ALDUNATE, J. Trypanosoma cruzi: a possible control of transfusion- induced chagas disease by phenolic antioxidants. Experimental Parasitology, Orlando, v. 71 , n. 4, p. $357-363$, 1990. DOI: 10.1016/00144894(90)90061-G

MACEDO, C. A. B.; MIZUBUTI, I. Y.; MOREIRA, F. B.; PEREIRA, E. S.; RIBEIRO, E. L. A.; ROCHA, M. A.; RAMOS, B. M. O.; MORI, R. M.; PINTO, A. P.; ALVES, T. C.; CASIMIRO, T. R. Comportamento ingestivo de ovinos recebendo dietas com diferentes níveis de bagaço de laranja em substituição à silagem de sorgo na ração. Revista Brasileira de Zootecnia, Viçosa, MG, v. 36, n. 6, p. 1910-1916, 2007. DOI: 10.1590/ S1516-35982007000800027

MICHAILOFF, A. A.; DAMO, B.; ROMANI, P.; SILVEIRA, M. F.; MAEDA, E.; WLODARKI, L.; FRANCISCO, L. F.; PROHMANN, G. Comportamento 
ingestivo e avaliação térmica de ovinos confinados. In: CONGRESSO BRASILEIRO DE ZOOTECNIA ZOOTEC, 25., 2015, Fortaleza. Anais... Fortaleza: Associação Brasileira de Zootecnistas, 2015. p. 1-3.

NAGAKAWA, Y.; TAYAMA, S. Cytotoxicity of propyl gallate and related compounds in rat hepatocytes. Archives Toxicology, Berlin, v. 69, n. 3, p. 204-208, 1995. DOI: $10.1007 / \mathrm{s} 002040050159$

NATIONAL RESEARCH COUNCIL - NRC. Nutrient requeriments of small ruminants: sheep, goats, cervids, and new world camelids. Washington, DC: National Academy Press, 2007. 362 p.

PINTO, C. M. F.; PINTO, C. L. O.; DONZELES, S. M. L. Pimenta Capsicum: propriedades químicas, nutricionais, farmacológicas e medicinais e seu potencial para o agronegócio. Revista Brasileira de Agropecuária Sustentável, Viçosa, MG, v. 3, n. 2, p. 108-120, 2013. DOI: $10.21206 /$ rbas.v3i2.225.

RASLAN, L. S. A. Aspectos comportamentais e fisiológicos de ovinos sem raça definida sob pastejo com e sem sobreamento. 2008. Dissertação (Mestrado em Zootecnia) - Universidade Estadual do Sudoeste da Bahia, 2008.

REECE, W. O. Dukes: fisiologia de animais domésticos. 12. ed. Guanabara Koogan: Rio de Janeiro, 2007. 926 p.

RODRIGUEZ-PRADO, M.; CALSAMIGLIA, S.; FERRET, A.; ZWIETEN, J.; GONZALEZ, L.; BRAVO, D. Effects of cinnamaldehyde-eugenol and capsicum on rumen fermentation and feeding behavior in beef heifers fed a highconcentrate diet. Journal of Animal Science, Champaing, v. 90, n. 6, p. 1879-1884, 2011. DOI: $10.2527 /$ jas $2010-3191$

SHAMI, N. J. E.; MOREIRA, E. A. M. Licopeno como agente antioxidante. Revista de Nutrição, Campinas, v. 17 , n. 2 , p. $227-236,2004$. DOI: 10.1590/S141552732004000200009

SILVA, A. L.; BORGES, L. S.; SANTANA, M. L. A.; BARROS JÚNIOR, C. P.; SOUSA, P. H.A.A.; ALMEIDA JÚNIOR, T. F.; FARIAS, L. A.; SOUSA JÚNIOR, S. C. Avaliação das variáveis fisiológicas de ovinos Santa Inês sob influência do ambiente semiárido piauiense. Journal of Animal Behavior and Biometeorology, São Paulo, v. 3 , n. 2, p. 69-72, 2015. DOI: 10.14269/2318-1265/jabb. v3n2p69-72

SILVA, D. J.; QUEIROZ, A. C. Análise de alimentos: métodos químicos e biológicos. 2. ed. Viçosa, MG: UFV, 2002. $178 \mathrm{p}$.

SNIFFEN, C. J.; O'CONNOR, J. D.; VAN SOEST, P. J.; RUSSELL, J. B. A net carbohydrate and protein system for evaluating cattle diets: II- Carbohydrate and protein availability. Journal Animal Science, Champaing, v. 70, n. 11, p. 3562-3577, 1992. DOI: 10.2527/1992.70113562x

SOARES, M.; WELTER, L.; KUSKOSKI, C. M.; GONZAGA, L.; FETT, R. Compostos fenólicos e atividade antioxidante de casca de uvas Niágara e Isabel. Revista Brasileira de Fruticultura, Jaboticabal, v. 30, n. 1 , p. 59-64, 2008. DOI: 10.1590/S010029452008000100013

SOARES, S. E. Phenolic acids as antioxidants, Revista de Nutrição, Campinas, v. 15, n. 1, p. 71-81, 2002. DOI: 10.1590/S1415-52732002000100008

SOUZA, M. S. Comportamento ingestivo de bovinos em sistema de pastejo rotacionado submetidos a diferentes estratégias de suplementação. 2007. Tese (Doutorado em Zootecnia) - Universidade Estadual Paulista, Jaboticabal.

TAGLIATI, C. A.; SILVA, R. P.; FÉRES, C. A. O.; JORGE, R. M.; ROCHA, O. A.; BRAGA, F. C. Acute and chronic toxicological studies of the Brazilian phytopharmaceutical product Ierobina. Revista Brasileira de Farmacognosia, Curitiba, v. 18, n. 1, p. 676-682, 2008. DOI: 10.1590/S0102-695X2008000500006

UNIVERSIDADE FEDERALDE VIÇOSA - UFV. Sistemas de Análises Estatísticas e Genéticas - SAEG. Versão 9.1. Viçosa, MG: UFV, 2007. 150 p.

VAN SOEST, P. J.; ROBERTSON, J. B.; LEWIS, B. A. Methods for dietary fiber neutral detergent fiber, and no starch polysaccharides in relation to animal nutrition. Journal of Dairy Science, Champaign, v. 74, n. 12 , p. $3583-3597,1991$. DOI: $10.3168 /$ jds.S00220302(91)78551-2

VERÍSSIMO, C. J.; TITTO, C. G.; KATIKI, L. M.; BUENO, M. S.; CUNHA, E. A.; MOURÃO, G. B.; OTSUK, I. P.; PEREIRA, A. M. F.; NOGUEIRA FILHO, J. C. M.; TITTO, E. A. L. Tolerância ao calor em ovelhas Santa Inês de pelagem clara e escura. Revista Brasileira de Saúde e Produção Animal, Salvador, v. 10, n. 1, p. 159-167, 2009. Disponível em: http://revistas.ufba.br/ index.php/rbspa/article/viewArticle/1079. Acesso em: 05 set. 2019.

WANG, M. Y.; WEST, B. J.; JENSEN, C. J.; NOWICKI, D.; SU, C. H.; PALU, A.; ANDERSON, G. Morinda citrofolia (Noni): a literature review and recent advances in noni research. Acta Pharmacologica Sinica, Shanghai, v. 23 , n. 12 , p. 1127-1141, 2002. DOI: PMID:12466051

YANG, W. Z.; BEAUCHEMIM, K. A.; RODES, L. A. Effects of grain processing, forage to concentrate ration, and forage particle size on rumen $\mathrm{pH}$ and digestion by dairy cattle. Journal of Dairy Science, Champaing, v. 84 , n. 10 , p. $203-2216$, 2001. DOI: $10.3168 /$ jds.S00220302(01)74667-X 
